\title{
POWER AND POLITICS IN THE SOVIET UNION
}


Also by Leo Cooper and from the same publishers

THE POLITICAL ECONOMY OF SOVIET MILITARY POWER SOVIET REFORMS AND BEYOND 


\section{Power and Politics in the Soviet Union}

The Crumbling of an Empire

\section{Leo Cooper}

Research Fellow

Centre of Soviet and East European Studies

University of Melbourne

Foreword by Philip Hanson

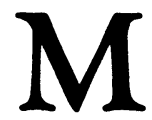


Softcover reprint of the hardcover 1st edition 1992

All rights reserved. No reproduction, copy or transmission of this publication may be made without written permission.

No paragraph of this publication may be reproduced, copied or transmitted save with written permission or in accordance with the provisions of the Copyright, Designs and Patents Act 1988, or under the terms of any licence permitting limited copying issued by the Copyright Licensing Agency, 90 Tottenham Court Road, London W1P 9HE.

Any person who does any unauthorised act in relation to this publication may be liable to criminal prosecution and civil claims for damages.

First published 1992 by

THE MACMILLAN PRESS LTD

Houndmills, Basingstoke, Hampshire RG21 2XS

and London

Companies and representatives

throughout the world

ISBN 978-1-349-12847-1 ISBN 978-1-349-12845-7 (eBook)

DOI 10.1007/978-1-349-12845-7

A catalogue record for this book is available from the British Library.

Copy-edited and typeset by Grahame \& Grahame Editorial, Brighton 
To Fanny 


\section{Contents}

Foreword by Philip Hanson viii

Preface $\quad \mathrm{x}$

1 Political Power and Soviet Society 1

2 Transformation of Power in the USSR 18

3 The Ruler, the Party and the Bureaucracy: traditional sources of power in the USSR 34

4 The Military and the KGB 54

5 The Government and the Parliament 72

6 Republics and Nationalities $\quad 88$

7 Soviet Society - People's Power? 107

8 Three Days that Shook the World 123

9 Whither the Soviet Union? 147

Bibliography $\quad 154$

Index 158 


\section{Foreword by Philip Hanson}

Leo Cooper has written a most interesting book on the evolution of political power in Russia during the Gorbachev period. That period may go down in history as the last years of the Soviet empire, so how and why political power fragmented as it did under Gorbachev is, to put it mildly, an interesting question. It was assuredly not Mikhail Gorbachev's intention in 1985 to preside over the crumbling of the Soviet superpower. That gap between intention and outcome is one of the things on which Dr Cooper's book sheds light.

In comparison with some who have written on the process of social and political change in the Soviet Union, Dr Cooper puts considerable emphasis on the inheritance from the political culture of Tsarist Russia. In Chapter 7 he notes the growing sophistication and higher educational levels of today's Russian population, in comparison with the past; but he attaches less weight to this 'modernization from below' than do some analysts, and correspondingly more to the legacy of the past - both the Soviet and the pre-Soviet past.

Many of the events of 1989-91 seem to fit his diagnosis. The rise and rise of nationalist sentiments, the failure of non-nationalist social and political groupings to gel into effective movements and parties, the developing free-for-all in the economy - all of these tendencies suggest a society in which the evolution of attitudes to authority, to work and to citizenship had been not frozen, but severely impeded in the course of the Soviet version of modernization.

Indeed, it seems to me that, far from condemning the communist order for destroying the nation's cultural heritage, as so many Russian intellectuals do, one might well accuse it with greater force of just the opposite: of preserving so much that was bad about the past. It is one of the oddities of authoritarianism of the Soviet type that it acts like a thick layer of ice over society, keeping some pretty ugly mastodons fresh. And not just fresh, but in a state of suspended animation from which they can all too easily be resuscitated.

Just as neo-nazism has emerged at its most unreconstructed from what used to be East Germany, so anti-Semitism and several malign varieties of 
nationalism have turned up alive and well in the Soviet successor-states. That is to say, they emerged to public view once the power system analysed by Dr Cooper was allowed to crumble. There are of course countervailing and encouraging tendencies as well, as Dr Cooper shows. But much that is atavistic has been preserved by censorship and authoritarian rule. This is not, in the Soviet case, because the official doctrine encouraged primitive antagonisms, but because it neither destroyed them nor allowed them to be exposed to the weeding-out process of public debate.

One such unhelpful survival of the past is the tendency of the present Russian leadership to reach for the mantle of the old imperial Union centre. As the Soviet Union goes into liquidation, a great deal now depends on the ability of Russian leaders to accept the limitations on their power that are now desirable.

Philip Hanson Geneva, December 1991 


\section{Preface}

Of all the radical changes which have taken place in the Soviet Union since the introduction of perestroika and glasnost, none appear to have had a more profound influence on the course of events in that country than the fragmentation of its power.

The importance of power in the Soviet Union is not only due to its implications for foreign policy, especially in its dealing with the West, but also because power is a means of reforming the Soviet economy and society. Historically and traditionally, the Russians as well as the Soviets have always required authority and the power of the state had always been accepted by the population. It is for this reason that power is so crucial in the Soviet Union in dealing with issues such as economic reforms, social transformation and the retention of the unity of the country.

This is a complex question, for while one source of power and a single authority existed all along the Soviet rule, other sources of power such as the parliament, trade unions, the church and society at large, only began to manifest themselves during the course of perestroika.

The adverse economic situation, for which perestroika is generally blamed, could be attributed in no small measure to the diffusion of state power and its fragmentation into its component parts. On the level of the Union, it has led to a break up of what was known as the USSR and the emergence of a number of governments claiming sovereignty and full independence. The fragmentation of power led to a situation where there ceased to be a clear distinction between the legislative and the executive, where there is no certainty whether a law or presidential decree could be enforced - in fact they are being disregarded. On the republican level, state power is dispersed among different echelons of the legislative and executive branches of those in authority - from the president down to the lowest level of local government - and no one is quite certain of who is in charge. The effects of this fragmentation can be observed in all aspects of Soviet life. There seems to be a complete breakdown of authority. The coup of August 1991 was an attempt to reintroduce the former system of power under which there was semblance of law and order. The coup may have succeeded but for the advanced stage of disintegration of the USSR and the fragmentation of power which came as a result of the reforms.

The objective of this study is to analyse the nature of the transformation 
of power in the Soviet Union from the supreme power in the hands of Stalin, through the power of the Politburo after his death, to the complete fragmentation into its component parts such as government, parliament, bureaucracy, military etc. In general terms the study will attempt to examine the changes which occurred as a result of the division of power and their implications for the future of the former Soviet Union. Can the situation be remedied without a regression to authoritarian rule, or might a Western style of democracy emerge? It will also investigate the relative strength of the centrifugal forces in the USSR that are speeding up the break up of the Union, and those that are working for its retention.

LEO COOPER 